УДК 633.34:631.816.2:631.85

(C) 2014

Крамарьов С. М., доктор сільськогосподарських наук, Артеменко С. Ф., кандидат сільськогосподарських наук

ДУ Інститут сільського господарства степової зони НААН України

Писаренко П. В., доктор сільськогосподарських наук

Полтавська державна аграрна академія

\title{
ЕФЕКТИВНІ ЕЛЕМЕНТИ ТЕХНОЛОГІЇ ВИРОЩУВАННЯ СОЇ В УМОВАХ ПІВНІЧНОГО СТЕПУ
}

\section{Рецензент - докор сільськогосподарських наук В. М. Писаренко}

\begin{abstract}
Інокулячія та інкрустація насіння в технологї вирошування кожної культури займає важливе значення. Обробка посівного матеріалу перспективними штамами азотфіксуючих бактерій позитивно вплинула на потенціал продуктивності азотфіксації сої й, як наслідок, на врожай даної культури. На ділянках, де насіння за інокуляції було оброблено штамами 46 та 626 кількість бульбочок на одній рослині зросла в 3,3 разу, а їх маса вдвічі. Ці посіви формували

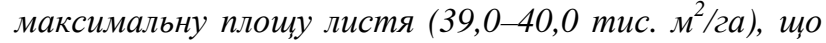
перевищувала контрольні ділянки на 17,8-20,8\%. Кількість бобів зросла на 11,7-17,4\%. Передпосівна інокулячія насіння азотфіксуючими штамами бульбочкових бактерій X9; 626а; 46 забезпечила кращчі умови для азотфіксаџї та досить високу насіннєву продуктивність сої. Урожайність насіння сої, де проводили передпосівну обробку насіння перспективними итамами бульбочкових бактерій, зросла на 11,9-15,2 \%. Проведення інкрустації насіннєвого матеріалу сої плівкоутворювачем Марс EL та препаратом Антистрес, щзо містить калій фосфорнокислий разом із молібденом та бором, сприяла підвищенню польової схожості на 10,8-11,8\%. Використання ичи препаратів забезпечило формування більшої висоти рослин сої на 9,6-14,2 \%, а кількість азотфіксуючих бульбочок зросла на 26,3-39,5\%. Посіви сої формували більшу площу асиміляційної листкової поверхні на 26,7\% за інкрустащиї насіння з використанням препарату антистрес, а сумісно з комплексонатами металів молібдену $і$ бору цеей показник зростав до 53,5\%. Найкраший врожай насіння $(2,18 \mathrm{~m} / 2 a)$, формували посіви сої з використанням для інкрустації посівного матеріалу препарату антистрес $(200 \mathrm{2} / \mathrm{m})$ і комплексонатів металів молібдену й бору (100 2/m кожного) та протруйника гранівіт $(2,5 \mathrm{\Omega} / \mathrm{m})$.
\end{abstract}

Ключові слова: інокулячія, азотфіксуючі бактерії, інкрустачія, насіння, протруйник, антистрес, комплексонати металів молібдену і бору, соя.

Постановка проблеми. У процесі вирощування кожної сільськогосподарської культури перед товаровиробником постає першочергове завдання щодо створення сприятливих умов для реалізації іiі потенціальних можливостей. У зв'язку з розширенням посівних площ такої зернобобової культури як соя виникає питання з'ясування та формування умов живлення, щоб забезпечити високу ії продуктивність. Важливим фактором стримування зростання продуктивності сої $є$ недостатньо удосконалена система удобрення цієї культури. Як відомо 3 літературних джерел, соя на формування 1 ц насіння потребує 7,2-10,0 кг азоту, 1,8-4,0 кг фосфору та 2,2-4,4 кг калію. Серед макроелементів рослини сої найбільше засвоюють азот. Завдяки здатності сої до фіксації азоту з повітря та проведення інокуляції іiі насіння ця культура забезпечує свої потреби в азоті майже на $70 \%$ [1-6].

Особливого значення в сучасних умовах набуває проблема ресурсо- та енергозбереження за використання мінеральних добрив під дану культуру. Це обумовлює проведення подальшого пошуку нових шляхів вирішення цієї проблеми за раціонального й ефективного застосування різних препаратів та мінеральних добрив.

Аналіз основних досліджень і публікацій, у яких започатковано розв'язання проблеми. Соя - унікальна рослина: завдяки успішному поєднанню двох важливих процесів фотосинтезу та біологічної фіксації азоту, - вона забезпечує свої потреби та покращує азотний баланс грунту і $є$ добрим попередником для інших культур. Біологічна здатність даної культури до симбіотичного типу живлення завдяки бульбочковим бактеріям роду Rhizobium забезпечує рослини фіксованим атмосферним азотом у формі органічних сполук в необмеженій кількості й у найбільш необхідний період росту і розвитку рослин, що дає можливість формувати стабільні та екологічно чисті врожаї. Тому в сучасних умовах досить актуальним $є$ вирішення питання азотфіксації бобових культур за застосування біологічних препаратів на основі перспективних бульбочкових бактерій та використання мікроелементів для підвищення продуктивності рослин сої. 


\section{СІЛЬСЬКЕ ГОСПОДАРСТВО. РОСЛИННИЦТВО}

Високий ефект від застосування інокуляції спостерігається на грунтах, де відсутні або низькопродуктивні специфічні ризобії. Так, на чорноземних грунтах переважають в основному малоактивні бульбочкові бактерії з низьким рівнем азотфіксації. Широке застосування біологічного азоту для бобових рослин є одним із альтернативних шляхів одержання екологічно чистого продукту для потреб харчування людини та годівлі тварин. Передпосівна інокуляція та інкрустація насіння сої повинні стати важливими агротехнічними заходами ресурсо- та енергозберігаючої технології вирощування даної культури.

Мета і завдання досліджень. Метою наших досліджень було вивчити і розробити найбільш ефективні заходи щодо системи живлення сої для підвищення ii продуктивності, за сумісного використання інокуляції та інкрустації насіння й покращити іiі стартові можливості. У зв'язку 3 цим необхідно було вивчити і дати оцінку перспективним i конкурентоздатним штамам бульбочкових бактерій сої та виявити їх азотфіксуючий потенціал в умовах північного Степу. 3'ясувати вплив мікроелементів при інкрустації насіння на продуктивність рослин сої.

Завдання дослідження - визначити та обгрунтувати ефективні агрозаходи щодо системи живлення рослин сої 3 використанням перспективних штамів бульбочкових бактерій за інокуляції та інкрустації іiі насіння мікроелементами молібденом і бором.

Науково-дослідна робота виконувалася згідно 3 тематичними планами наукових досліджень Інституту сільського господарства степової зони НААН та у відповідності з комплексною державною програмою «Зернові і олійні культури» (розробити адаптивну технологію вирощування сої для впровадження в аграрне виробництво).

Об'єкт досліджень - оптимізація системи живлення рослин сої шляхом використання інокуляції перспективними бульбочковими бактеріями та інкрустації насіння.

Методи досліджень. Науково-дослідна робота щодо вивчення цього питання проводилася на Ерастівській дослідній станції Інституту сільського господарства степової зони НААН.

Для інокуляції насіння сої використовували сім штамів роду Rhizobium: 634б; 626a; M8; X9; Д2; №30; №46, які одержали в південному філіалі Інституту сільськогосподарської мікробіології. Повторність у досліді - триразова. Для боротьби з бур'янами застосовували гербіцид «Харнес» у дозі 2 л/га під передпосівну культивацію. Кількість бульбочок у грунті визначали за існуючою методикою Г. С. Посипанова.
Перед сівбою проводили передпосівну інкрустацію насіння сої. Насіннєвий матеріал обробляли сумішшю, до складу якої входять такі компоненти: протруйник «Гранівіт» $(2,0$ л/т), плівкоутворювач «Марс EL» $(200$ г/т), препарат «Антистрес» (200 г/т, ППКФ «Імпторгсервіс»).

Для зведення до мінімуму осипання протруйника 3 поверхні зерна та зниження негативного впливу його на обслуговуючий персонал під час виконання посівних робіт використовували плівкоутворювач «Mapc EL». За цього елементу технології з'являється можливість висівати інкрустоване насіння навіть у напівсухий грунт. За несприятливих погодних умов таке насіння не зазнає пліснявіння в грунті. За оптимального зволоження посівного шару грунту та встановлення сприятливого температурного режиму насіння сої енергійно проростає й з'являються дружні сходи.

Попередником сої в сівозміні була пшениця озима. Насіння сої висівали за стійкого прогрівання грунту на глибині $10 \mathrm{~cm}$ до $10{ }^{\circ} \mathrm{C}$. Сівбу сої проводили відповідно до схеми польового досліду широкорядним способом із міжряддям 45 см і нормою висіву 500 тис. шт./га схожих насінин. Площа посівної ділянки дорівнювала $172,8 \mathrm{~m}^{2}$, облікова - 108,0 м². Повторність у досліді - триразова. В експерименті висівали насіння сої ранньостиглого сорту Аметист, районованого для степової зони. Проти бур'янів застосовували грунтовий гербіцид «Харнес» під передпосівну культивацію в дозі 2 л/га та проводили міжрядний обробіток грунту в фазі цвітіння рослин сої.

Ірунти дослідних ділянок - чорноземи звичайні малогумусні важкосуглинкові на карбонатному лесі. Вміст гумусу в орному шарі грунту становить 3,8-4,0 \%, валового азоту - 0,23-0,26, фосфору - 0,11-0,12, калію - 2,0-2,5\%. Реакція грунтового розчину - нейтральна ( $\mathrm{pH}$ водної витяжки - 6,5-7,0).

Метеорологічні умови за роки проведення досліджень були різноманітними, що в повній мірі характеризували особливості клімату даної зони вирощування.

Результати досліджень. Продуктивність рослин сої суттєво залежить від наявності необхідних елементів мінерального живлення в грунті та їх надходження в основні фази росту і розвитку.

Проведений аналіз одержаних аналітичних даних стосовно вмісту в грунті рухомих форм поживних речовин і враховуючи азотфіксуючу здатність сої, ми дійшли висновку, що для рослин цієї культури наявна кількість у грунтовому розчині мікроелементів молібдену та бору є недостатньою для забезпечення потреб рослин протягом вегетації. 


\section{СІЛЬСЬКЕ ГОСПОДАРСТВО. РОСЛИННИЦТВО}

Інкрустація насіння сої цими мікроелементами покращує надходження їх сполук у ранні фази розвитку рослин, що створює кращі стартові можливості та забезпечує сприятливі умови для повного розкриття потенційних можливостей даної культури. Важливим елементом у технології вирощування сої $\epsilon$ інокуляція насіння перспективними штамами бульбочкових бактерій, аби забезпечити високий азотфіксуючий потенціал i продуктивність рослин даної культури.

Одержані біометричні показники характеризують умови росту і розвитку рослин сої в різні фази вегетаційного періоду. Проведений облік висоти рослин у фазу цвітіння показав, що найвищі показники формували посіви сої, насіння яких було оброблене штамами Д2, 30 та 46. На цих ділянках рослини сої за роки досліджень сягали висоти 72-74 см і перевищували контроль на 5,9-8,8\%. Дещо менші відмінності по висоті відносно дії вищезгаданих бульбочкових бактерій спостерігалася в фазу повної стиглості насіння. Дослідження по симбіотичній азотфіксації проводили в період першого, другого трійчастого листка - налив бобів. У фазі перший та другий трійчастий листок на кореневій системі кожної рослини нараховували по 3-7 маленьких бульбочок, на початку цвітіння - від 12 до 18 штук. Найбільш інтенсивне утворення бульбочок на кореневій системі відбувалось у період повного цвітіння - налив бобів. У фазу формування насіння на ділянках, де застосовували штами X9, 30 та Д2, кількість бульбочок сягала на одній рослині 19,9-22,8; дещо вищі показни- ки їх утворення (24,3-24,4 штук) було відмічено за інокуляції насіння штамами 46 та 626a. У роки 3 достатнім зволоженням кількість і маса бульбочок була значно більшою порівняно із посушливими погодними умовами. Бульбочки в основному розміщувалися на головному корені та розгалуженнях першого порядку на глибині 0-15 см й мали світло-рожеве забарвлення, що свідчить про їх досить високий ступінь азотфіксуючої активності (табл. 1).

Важливим показником фотосинтетичної діяльності посіву є площа асиміляційної листової поверхні. Проведені дослідження по площі листкової поверхні показали, що найвищі показники формували посіви сої в фазу «цвітіння - налив бобів». Максимальну площу листя (39,040,0 тис. $\mathrm{m}^{2} /$ га) мали посіви, де насіння було оброблене штамами X9, 30, 46. Інокуляція насіння штамами бактерій 626a, 6346, М8 та Д2 сприяла формуванню дещо меншої (37,5-38,6 тис. м²/га) площі листової поверхні, але більшої порівняно 3 контролем на 13,3-16,6\%.

Умови, що складались впродовж всієї вегетації, за період проведення досліджень у посівах сої внаслідок використання інокуляції насіння сої перспективними штамами бульбочкових бактерій мали позитивний вплив на формування елементів структури врожаю, а також на всю продуктивність агроценозу. Проведений аналіз елементів структури врожаю сої показав, що більша кількість продуктивних гілок і бобів формувались у рослин сої в разі застосування інокуляції насіння.

\section{1. Вилив азотфіксуючих бактерій на продуктивність сої, 2004-2006 рр.}

\begin{tabular}{|c|c|c|c|c|c|c|c|}
\hline \multirow{2}{*}{$\begin{array}{c}\text { Варіанти } \\
\text { штами }\end{array}$} & \multicolumn{2}{|c|}{$\begin{array}{c}\text { Кількість } \\
\text { бульбочок } \\
\text { на } 1 \text { рослині }\end{array}$} & \multirow{2}{*}{$\begin{array}{c}\text { Висота } \\
\text { рослин, } \\
\text { см }\end{array}$} & \multicolumn{2}{|c|}{ Кількість } & \multirow{2}{*}{$\begin{array}{c}\text { Площа листко- } \\
\text { вої поверхні, } \\
\text { тис. } \text { м }^{2} / \text { га }\end{array}$} & \multirow{2}{*}{$\begin{array}{c}\text { Урожай насіння, } \\
\text { т/га }\end{array}$} \\
\hline & $\begin{array}{c}\text { кількість, } \\
\text { шт. }\end{array}$ & $\begin{array}{c}\text { маса, } \\
\Gamma\end{array}$ & & $\begin{array}{l}\text { гілок, } \\
\text { шт. }\end{array}$ & $\begin{array}{c}\text { бобів, } \\
\text { шт. }\end{array}$ & & \\
\hline Контроль & 7,4 & 0,57 & 68 & 1,9 & 33,4 & 33,1 & 1,51 \\
\hline 6346 & 16,6 & 0,93 & 68 & 2,2 & 35,8 & 38,4 & 1,66 \\
\hline $626 a$ & 24,4 & 1,14 & 71 & 2,3 & 39,4 & 37,5 & 1,69 \\
\hline M8 & 18,3 & 0,99 & 69 & 2,3 & 36,0 & 38,2 & 1,61 \\
\hline X9 & 19,9 & 0,96 & 70 & 2,1 & 38,3 & 39,0 & 1,68 \\
\hline Д2 & 22,8 & 1,10 & 72 & 2,1 & 35,4 & 38,6 & 1,63 \\
\hline 30 & 22,0 & 0,96 & 74 & 2,1 & 37,3 & 39,9 & 1,67 \\
\hline 46 & 24,3 & 1,16 & 74 & 2,2 & 39,2 & 40,0 & 1,74 \\
\hline
\end{tabular}

$\mathrm{HIP}_{05} \mathrm{~T} / г \mathrm{a}$

$0,07-0,13$ 


\section{СІЛЬСЬКЕ ГОСПОДАРСТВО. РОСЛИННИЦТВО}

Так, за обробки насіння сої штамами бульбочкових бактерій 30, X9, 46 нараховували більшу кількість бобів (11,7-17,4\%) перед збиранням врожаю, що певним чином позначилось на формуванні насіннєвої продуктивності.

Кінцевим критерієм ефективності застосування передпосівної обробки насіння сої азотфіксуючими штамами бульбочкових бактерій є врожайність. Цей показник визначається індивідуальною насіннєвою продуктивністю бобової рослини.

Проведений аналіз зернової продуктивності сої за весь період досліджень показав, що передпосівна інокуляція насіння новими штамами бульбочкових бактерій X9; 626а; 46 забезпечила кращі умови для азотфіксації та досить високу насіннєву продуктивність сої. Найвищу урожайність насіння сої (17,4 ц/га) одержали на ділянках, де проводили передпосівну обробку насіння перспективним штамом бульбочкових бактерій 46. Дещо меншу врожайність (16,7-16,9ц/га) сформували посіви сої на ділянках, де інокуляція проводилась штамами 30, X9 і 626а.

У технології вирощування сої важливе значення має такий агрозахід, як інкрустація насіння, що створює сприятливі стартові умови для даної культури.

В одержанні дружних, повноцінних сходів важливим показником $\epsilon$ польова схожість насіння. За період проведення досліджень на контрольних ділянках без використання допосівної інкрустації проросло лише 79,5\% насіння сої.

Застосування протруйника «Гранівіт» $(2,5$ л/т) із плівкоутворювачем «Mapc EL» сприяло незначному $(4,2 \%)$ збільшенню кількості пророслого насіння. Використання тільки препарату «Антистрес», що містить калій фосфорнокислий (легко розчинне добриво) та плівкоутворювач, зумовило підвищення схожості на 6,0-6,4\% порівняно 3 контролем. Інкрустація насіння сої протруйником сумісно 3 препаратом «Антистрес» або плівкоутворювачем «Mapc EL» із молібденом і бором сприяла підвищенню польової схожості на 10,8-11,8 \% .

Отримані біометричні дані на період цвітіння показали, що висота рослин сої суттєво залежала від погодних умов, зокрема від рівня зволоження, а також від інкрустації насіння. Аналіз біометричних показників рослин показав, що допосівна інкрустація насіння позитивно впливає на ростові процеси сої впродовж вегетації.

Так, рослини сої на контрольних ділянках ма- ли висоту 42,9 см, а за застосування протруювача разом із плівкоутворювачем «Марс EL»44,7 сантиметра. У разі застосування плівкоутворювача, протруйника, комплексонату металів молібден або бор (готуючи насіння до сівби) висота рослин сої становила 46,5-46,8 сантиметра.

Найбільшу висоту (48,3-49,0 см) мали рослини сої на ділянках, де насіння перед сівбою було оброблене плівкоутворювачем, препаратом «Антистрес» і комплексонатами металів молібдену й бору та протруйником.

Площа асиміляційної листкової поверхні є важливим кількісним показником фотосинтетичної діяльності посіву.

На контрольних варіантах без проведення інкрустації посіви формували асиміляційну листкову поверхню 21,7 тис. м²/га, а за застосування протруйника 3 плівкоутворювачем «Mapc EL» вона збільшувалася до 26,2 тис. м²/га. За використання для інкрустації препарату «Антистрес» 3 протруйником асиміляційна поверхня зростала до 27,5 тис. $\mathrm{m}^{2} /$ га.

Найбілышу асиміляційну поверхню (33,7 тис. м²/га) формували посіви сої за інкрустації насіння протруйником, препаратом «Антистрес» із комплексонатами металів молібдену і бору.

Використання мікроелементу молібдену обумовило не тільки збільшення кількості бульбочок азотфіксуючих бактерій на коренях сої, але й посилило відновлення нітратів до аміаку, що знизило непродуктивні втрати азоту даною культурою.

Застосування інкрустації насіння певною мірою вплинуло на складові елементи морфологічної структури урожаю сої. Під впливом застосованого мікроелемента молібдену зросла фіксація атмосферного азоту, а завдяки бору покращилося проростання пилку, знизилась кількість пустоцвіту й посилився розвиток репродуктивних органів.

Проведений аналіз структури врожаю показав, що рослини сої формували значно більшу кількість гілок, бобів та насіння в них.

У результаті проведених досліджень й одержаних урожайних даних слід відзначити високу ефективність застосування інкрустації насіння сої препаратом «Антистрес» та комплексонатами металів молібдену і бору разом із протруйником. За такого застосування вищезгаданих засобів за роки досліджень формувалася найбільша зернова продуктивність рослин сої 2,18 т/га (табл. 2). 
СІЛЬСЬКЕ ГОСПОДАРСТВО. РОСЛИННИЦТВО

2. Вилив інкрустації насіння сої на продуктивність ї̈ посівів, 2009-2011 рр.

\begin{tabular}{|c|c|c|c|c|}
\hline Варіанти досліду & $\begin{array}{c}\text { Висота рослин на } \\
\text { період цвітіння, } \\
\text { см }\end{array}$ & $\begin{array}{c}\text { Бульбочки } \\
\text { на 1 рос- } \\
\text { лині, шт. }\end{array}$ & $\begin{array}{c}\text { Площа лист- } \\
\text { кової поверх- } \\
\text { ні, тис. м²/га }\end{array}$ & $\begin{array}{c}\text { Урожай } \\
\text { насіння сої, т/га }\end{array}$ \\
\hline Контроль (вода) & 42,9 & 20,5 & 21,7 & 1,82 \\
\hline $\begin{array}{c}\text { Протруйник, 2,5 л/т } \\
+ \text { «Марс EL», 200 г/т }\end{array}$ & 44,7 & 24,1 & 26,2 & 1,91 \\
\hline «Антистрес», 200 г/т & 46,9 & 25,9 & 27,5 & 2,02 \\
\hline $\begin{array}{c}\text { Мо, 100 мл/т + протруйник, 2,5 л/т } \\
+ \text { «Марс ЕL», 200 г/т }\end{array}$ & 46,8 & 25,2 & 30,5 & 2,06 \\
\hline $\begin{array}{c}\text { В, 100 мл/т + протруйник, 2,5 л/т } \\
+ \text { «Марс ЕL», 200 г/т }\end{array}$ & 46,5 & 27,6 & 30,1 & 2,08 \\
\hline $\begin{array}{c}\text { «Антистрес», 200 г/т } \\
+ \text { протруйник, 2,5 л/т }\end{array}$ & 47,0 & 28,3 & 33,3 & 2,09 \\
\hline $\begin{array}{c}\text { «Антистрес», 200 г/т + Мо, 100 мл/т } \\
+ \text { В, 100 мл/т + протруйник, 2,5л/т }\end{array}$ & 49,0 & 28,6 & 33,7 & 2,18 \\
\hline
\end{tabular}

$$
\mathrm{HIP}_{05} \mathrm{~T} / \mathrm{\Gamma a}
$$

Висновки: 1. Одержаний експериментальний матеріал дає змогу стверджувати, що застосування такого заходу як інокуляції насіння суттево активізує діяльність азотфіксуючого потенціалу рослин сої, підвищує показники морфологічної структури та насіннєву продуктивність $(11,2-15,2 \%)$ у порівнянні 3 ділянками без використання азотфіксуючих бактерій. Кращими штамами для проведення інокуляції насіння сої були X9, 626а та 46.

\section{БІБЛІОГРАФІЯ}

1. Бабич А. О. Сучасне виробництво і використання сої / А. О. Бабич. - К. : Урожай, 1993.$427 \mathrm{c}$.

2. Бабич А. О. Проблема фотосинтезу і біологічної фіксації азоту бобовими культурами / Бабич А. О., Петриченко В. Ф., Адамень В. В. // Вісник аграрної науки. - 1996. - №2. - С. 34-39.

3. Бабич А. О. Розміщення посівів і технологія вирощування сої в Україні / Бабич А. О., Колісник С. І. та ін. // Пропозиція. - 2002. - №5. C. $38-40$.
4. Колісник
C. I. Ефективність застосування

0,04-0,07

2. Позитивний вплив на продуктивність посівів сої мали заходи щодо проведення інкрустації насіння водорозчинними сполуками, що містить калій фосфорнокислий та комплексонати металів молібдену та бору. Найкращий врожай насіння (2,18 т/га), за різних погодних умов, формували посіви сої з використанням для інкрустації посівного матеріалу препарату «Антистрес» (200 г/т) і комплексонатів металів молібдену і бору (100 г/т кожного) та протруйника «Гранівіт» $(2,5$ л/т).

різних штамів бактеріальних препаратів при вирощуванні сої / Колісник С. І., Венедіктов О. М., Петриченко Н. М. // Корми і кормовиробництво. - 2003. - Вип. 51. - С. 122-125.

5. Бобро М. А. Урожайність сої залежно від застосування біологічних препаратів / Бобро М. А., Огурцов Є. М., Міхеєв В. Г. // Корми і кормовиробництво. - 2006. - Вип. 58. - С. 231-236.

6. Фатеев А. И. Значение микроелементов в ферментативных процессах в растениях / А. И. Фатеев, С. П. Полянчиков // Агроном. 2008. - № 4. - С. 24-26. 